\title{
Penerapan Strategi Pembelajaran Quick On The Draw Untuk Meningkatkan Minat Dan Hasil Belajar Matematika Siswa Kelas II D SDN 69 Kota Bengkulu
}

\author{
Fitria Ekawati \\ Program Magister Pendidikan Dasar Universitas Bengkulu. \\ Fitriaekawati06@gmail.com \\ Agus Susanta \\ Program Magister Pendidikan Dasar Universitas Bengkulu.

\section{Daimun Hambal} \\ Program Magister Pendidikan Dasar Universitas Bengkulu.
}

\begin{abstract}
This study aimed to improve a) the activities of teachers and students, b) interest in learning mathematics students, c) the results of mathematics learning students of class II D SDN 69 Kota Bengkulu. The research method was classroom action research. This research was conducted in class II D SDN 69, Bengkulu City consisting of 25 students. The results of this study were an increase in teacher activity in the first cycle obtained an average score of 22.5, increased in the second cycle with an average score of 24.5 , and increased in the third cycle to 28.5. Increased activity of students in the first cycle obtained an average score of 25.5, and increased in the second cycle to an average score of 27, and then increased again in the third cycle to 31.5. In students' interest in learning mathematics in the first cycle the percentage was $77.6 \%$, increasing in the second cycle by $86 \%$, increasing again in the third cycle to $89.2 \%$. The improvement of cognitive cognitive learning outcomes of students in the first cycle was average value (66.4) with classical learning completeness (44\%), increased in the second cycle the average score (69.4) and classical learning completeness (64\%), increased in cycle III (80.6) and classical learning completeness (88\%). Then it could be concluded that the application of quick on the draw learning strategies could increase the interest and results of learning mathematics of students in class II D SDN 69 Kota Bengkulu.
\end{abstract}

Keywords:Kata Kunci : Mathematics Learning Outcomes, Interest in Learning Mathematics, Quick On The Draw Learning Strategy. 


\section{Pendahuluan}

Matematika merupakan dasar sumber dari ilmu lain sehingga matematika dikatakan sebagai ratu atau ibunya ilmu pengetahuan. Dengan kata lain, banyak ilmu yang penemuan dan pengembangannya bergantung dari matematika. Pada kenyataannya matematika adalah salah satu mata pelajaran yang sering dianggap susah untuk dipahami. Hal ini bisa dilihat dari kurangnya minat belajar siswa terhadap mata pelajaran matematika yang menyebabkan hasil belajar siswa kurang memuaskan.

Pada tahun ajaran 2018/2019 saya ditugaskan oleh kepala sekolah mengajar di kelas 2. Selama semester 1, saya menggunakan metode ceramah selama proses pembelajaran, siswa mendengarkan penjelasan dari guru, terkadang guru tidak menggunakan media ajar karena saya diberikan tugas administrasi sekolah, kegiatan sekolah, dan pelatihan-pelatihan di luar sekolah, lalu guru melakukan tanya jawab dengan siswa, dan selanjutnya siswa di berikan tugas untuk mengerjakan soal, siswa tidak tertarik mengerjakan soal tersebut dikarenakan ada yang tidak mengerti, ada yang malas karena tidak ada yang menarik dilakukan oleh guru. Hal ini menyebabkan siswa mengalami kejenuhan yang berakibat kurangnya minat siswa dalam belajar. Oleh karena itu, diperlukan suatu strategi pembelajaran yang tepat agar dapat menumbuhkan minat belajar siswa dalam belajar matematika dan mencapai tujuan pembelajaran yang telah ditentukan. Menurut Hamalik dalam Suprihatiningrum, (2016:149) strategi pembelajaran adalah keseluruhan metode dan prosedur yang menitikberatkan pada kegiatan siswa dalam proses belajar-mengajar untuk mencapai tujuan tertentu. Pada pembelajaran matematika, jika strategi pembelajaran yang digunakan tepat dan menarik, siswa akan antusias dan meningkatkan minat siswa untuk mengikuti pembelajaran matematika sehingga tujuan pembelajaran akan tercapai.

Menurut teori belajar konstruktivisme, peserta didik adalah aktif dan mencari untuk membuat pengertian tentang apa yang ia pahami, ini berarti belajar membutuhkan untuk fokus pada skenario berbasis masalah, belajar berbasis proyek, belajar berbasis tim, simulasi dan penggunaan tekhnologi (Rusman, 2017:112). Sedangkan Vygotsy dalam Widiana (2009:68) menyatakan bahwa proses belajar tidak dapat dipisahkan dari aksi (aktivitas) dan interaksi, karena persepsi dan aktivitas berjalan seiring secara dialogis. Pengetahuan tidak terpisahkan dari aktivitas dimana pengetahuan itu dikonstruksikan dan dimana makna diciptakan, serta dari komunitas budaya dimana pengetahuan didesiminasikan dan diterapkan. Penciptaan makna terjadi melalui aktivitas interaksi sosial. Kedua teori ini menampakkan suatu gambaran pembelajaran aktif untuk siswa dalam bentuk diskusi yang membantu memperjelas pemikiran siswa.

Salah satu strategi yang relevan dengan kedua teori diatas adalah dengan menerapkan pembelajaran yang mengarahkan siswa untuk melakukan kegiatan berdiskusi dalam kelompok. Pembelajaran dengan pendekatan kelompok memiliki potensi untuk mempengaruhi prestasi akademik siswa dalam matematika (Dhlamini dan Mogari, dalam Suryadinata, 2015:12). Selain itu menurut Hutagaol dalam Ariawan (2016:23) dalam siswa yang belajar dalam kelompok kecil lebih menerapkan kegiatan pemecahan masalah dibandingkan dengan siswa yang bekerja secara individu. Sejalan dengan itu, Hutagaol dalam Ariawan (2016:24) menyimpulkan bahwa faedah pemecahan masalah dilakukan secara berkelompok yaitu: (1) kelompok lebih banyak membawa pengalaman masing-masing daripada pengalaman individu; 
kelompok lebih banyak memberikan bermacam-macam saran/pendapat dibandingkan dengan seorang individu saja; (3) macam- macam pendapat yang berbeda lebih representatif daripada pendapat seorang saja; (4) dalam menyatukan perbedaan-perbedaan pendapat akan menjadi masalah yang lebih riil; dan (5) kelompok lebih produktif dalam memberikan kritik terhadap usulusul.

Salah satu pembelajaran diskusi kelompok yang dapat diterapkan adalah strategi quick on the draw. Strategi quick on the draw adalah salah satu strategi yang dapat diterapkan dalam pembelajaran matematika untuk membuat siswa lebih berminat dalam pembelajaran matematika. Quick on the draw merupakan pembelajaran yang lebih mengutamakan aktivitas dan kerja sama siswa dalam mencari, menjawab dan melaporkan informasi dari berbagai sumber dalam sebuah suasana permainan yang mengarah pada pacuan kelompok melalui aktivitas kerja tim dan kecepatannya

Sebagaimana dikemukakan oleh Ginnis (2008: 163) bahwa quick on the draw adalah sebuah aktivitas riset dengan intensif bawaan untuk kerja tim dan kecepatan. Ciri utama pada strategi quick on the draw adalah adanya kerja kelompok serta suasana pembelajaran yang menyenangkan dimana siswa tidak hanya duduk diam ditempat, tetapi siswa dapat bergerak dalam mengambil kartu soal dan menyerahkan jawaban.

Menurut Huriyanti dan Rosiyanti (2017:66) quick on the draw adalah strategi pembelajaran berbasis games. Sampai saat ini strategi pembelajaran quick on the draw belum banyak diterapkan dalam proses pembelajaran khususnya pelajaran matematika. Demikian juga halnya dengan penelitian yang ada, belum banyak penelitian yang membahas mengenai penerapan strategi pembelajaran quick on the draw dalam pembelajaran matematika.

Dari hasil refleksi diri yang dilakukan peneliti sebagai guru kelas 2 selama di SDN 69 Kota Bengkulu, masih terdapat lima permasalahan dalam proses belajar mengajar matematika di kelas, yaitu: a) Minat belajar siswa dan keterlibatan siswa dalam proses pembelajaran kurang optimal sehingga menjadi pembelajar yang pasif, b) Siswa kurang memperhatikan, mengobrol, mengganggu teman, bahkan sibuk dengan kegiatannya sendiri, c) Pembelajaran kurang menarik atau kurang menyenangkan bagi siswa, dan tidak adanya aktivitas belajar sambil bermain, sehingga pembelajaran menjadi membosankan, d) Saat guru memberikan soal siswa sangat lambat mengerjakan soal tersebut, dan terkadang jam pelajaran sudah habis namun soal belum terselesaikan, maka dengan menggunakan strategi pembelajaran quick on the draw, siswa terpacu untuk menyelesaikan soal dengan cepat sehingga nanti nya terbiasa mengerjakan soal dengan cepat, e) Hasil belajar matematika siswa rendah yaitu rata-rata 6,5 dan belum mencapai ketuntasan belajar. Dari hasil ulangan akhir semester 1 siswa didapatkan hasil belajar matematika siswa masih rendah yaitu rata-rata 6,5 atau belum mencapai ketuntasan belajar. Di SDN 69 Kota Bengkulu KKM mata pelajaran matematika ini lah yang nilainya paling rendah yaitu 70 , akan tetapi walau KKM nya sudah rendah dibandingkan mata pelajaran lain.

Tujuan penelitian ini adalah 1) Mengetahui bagaimanakah peningkatan aktivitas guru kelas II D SDN 69 Kota Bengkulu melalui strategi pembelajaran quick on the draw, 2) Mengetahui bagaimanakah peningkatan 
aktivitas siswa kelas II D SDN 69 Kota Bengkulu melalui strategi pembelajaran quick on the draw, 3) Mengetahui apakah penerapan strategi pembelajaran quick on the draw dapat meningkatkan minat belajar matematika siswa kelas II D SDN 69 Kota Bengkulu, 4) Mengetahui apakah penerapan strategi pembelajaran quick on the draw dapat meningkatkan hasil belajar kognitif matematika siswa kelas II D SDN 69 Kota Bengkulu.

\section{Metode}

Jenis Penelitian ini adalah Penelitian Tindakan Kelas (Classroom Action Research) yang direncanakan dalam siklus ke I sampai siklus ke-n. Winarni (2018:201) mengartikan PTK sebagai penelitian yang bersifat reflektif dengan melakukan tindakan- tindakan tertentu agar dapat memperbaiki dan atau meningkatkan kualitas proses dan hasil pembelajaran yang diselenggarakan secara profesional.

Model Penelitian tindakan kelas yang sering digunakan tidak terlalu sulit adalah model Kemmis dan Mc Taggart (Winarni, 2018:221). Model ini terdiri dari 4 komponen yaitu rencana, tindakan, observasi, dan refleksi.

Subjek penelitian ini yaitu siswa kelas II D SDN 69 Kota Bengkulu yang terdiri atas 25 siswa yaitu 15 siswa laki-laki dan 10 siswa perempuan. Penelitian ini dilakukan di kelas II D SDN 69 Kota Bengkulu yang beralamat di jalan WR Supratman Kelurahan Kandang Limun Kota Bengkulu.

Pada penelitian ini menggunakan strategi pembelajaran quick on the draw yang dalam kegiatan pembelajaran siswa dibagi dalam 5 kelompok berdasarkan jenis kelamin dan kemampuan akademik, kemudian guru menyiapkan 5 tumpukan kartu soal yang terdiri dari 5 macam warna sehingga setiap kelompok mengenali kartu soal kelompok masing-masing. Adapun prosedur penelitian ini memiliki 4 tahap, dalam tahap tersebut terdapat 7 langkah pelaksanaan strategi pembelajaran quick on the draw yaitu: a) Guru menyiapkan tumpukan kartu soal, Guru menyiapkan 5 tumpukan kartu soal, setiap kartu berisi satu soal yang akan dikerjakan siswa, b) kelompok. Guru membagi siswa kedalam 5 kelompok yang heterogen, masing-masing kelompok berjumlah 5 siswa, kemudian siswa duduk sesuai kelompok masing-masing. Masing- masing siswa ditentukan oleh guru nomor 1 sampai 5 agar siswa dapat mengenali tumpukan kartu soal mereka yang telah disiapkan di meja guru, c) Setiap kelompok diberikan bahan materi pelajaran Guru memberikan tiap kelompok bahan materi pelajaran yang sudah disesuaikan dengan tujuan pembelajaran untuk tiap siswa dalam tiap kelompok agar dapat menjawab soal yang akan diberikan. d) Guru menyampaikan aturan permainan, Membahas semua pertanyaan pada kartu soal. e) Guru menunjuk salah satu kelompok untuk menyampaikan jawaban dari kartu soal bernomor satu yang telah mereka jawab saat permainan, kemudian menunjuk salah satu kelompok lainnya untuk menyampaikan jawaban dari kartu soal bemomor dua dan seterusnya, f). Dengan bimbingan guru, siswa dapat menyimpulkan materi pelajaran Setelah pelajaran selesai, guru membimbing siswa menyimpulakan materi yang telah mereka pelajari dengan cara bertanya apa saja yang mereka pelajari hari ini, g) Guru memberikan penghargaan kepada kelompok yang dinyatakan menang dalam permainan. Pada saat melakukan perlombaan menjawab pertanyaan pada kartu soal, setiap kelompok berlomba menjawab pertanyaan dengan benar dan cepat. Kelompok yang tercepat itu lah yang menjadi pemenang dalam pembelajaran yang menggunakan strategi 
pembelajaran quick on the draw. Maka yang menang akan diberikan penghargaan/ hadiah.

\section{HASIL PENELITIAN}

\section{a. Deskripsi aktivitas pembelajaran Siklus I}

Berdasarkan hasil pengamatan dua orang pengamat untuk aktivitas kegiatan guru pada siklus I selama proses pembelajaran diperoleh rata-rata skor sebesar 22,5, rata rata skor ini termasuk ke dalam kategori "Cukup" Berdasarkan hasil pengamatan observasi aktivitas siswa siklus I diperoleh rata-rata skor yaitu sebesar 25,5. Skor tersebut sudah tergolong ke dalam baik.

\section{Refleksi Aktivitas Pembelajaran Siklus I}

Berdasarkan hasil analisis terhadap aktivitas guru, hal yang belum berhasil pada siklus I yaitu guru tidak membimbing siswa saat siswa berdiskusi dengan teman sekelompoknya dalam mencari informasi dan mengerjakan soal yang ada pada kartu soal, seharusnya guru membimbing siswa berdiskusi kelompok dan tidak terfokus untuk mengoreksi jawaban saja. Kemudian guru tidak meminta siswa mencatat semua informasi yang didapatkannya baik itu dari hasil diskusi kelompoknya, diskusi kelas dan penjelasan guru, seharusnya guru meminta siswa untuk mencatat informasi yang didapatnya agar dapat dipelajari lagi di rumah.

Berdasarkan hasil analisis aktivitas siswa, hal yang masih tergolong kurang pada siklus I yaitu siswa tidak mendapatkan bimbingan guru saat berdiskusi dengan teman sekelompoknya dalam mencari informasi dan mengerjakan soal yang ada pada kartu soal, seharusnya siswa mengingatkan guru untuk membimbingnya atau ada kelompok yang bertanya mengenai hal yang tidak mereka mengerti. Selain itu, siswa tidak mencatat semua informasi yang didapatkannya baik itu dari hasil diskusi kelompoknya, diskusi kelas dan penjelasan guru, seharusnya siswa lebih kreatif, tanpa dimintaoleh guru seharusnya siswa tetap mencatat hal-hal yang penting dalam pembelajaran.

\section{Siklus II}

Berdasarkan hasil pengamatan dua orang pengamat untuk aktivitas kegiatan guru pada siklus II selama proses pembelajaran diperoleh rata-rata skor sebesar 24,5, rata-rata skor ini termasuk ke dalam kategori "Baik". Pada aktivitas siswa, dilihat rata-rata skor pada proses pembelajaran yang diamati oleh dua orang pengamat pada siklus 2 diperoleh rata-rata skor yaitu sebesar 27. Skor tersebut sudah tergolong ke dalam baik.

\section{Refleksi Aktivitas Pembelajaran Siklus II}

Berdasarkan lembar observasi guru, hal yang belum berhasil atau masih termasuk kategori kurang pada siklus II yaitu guru belum meminta siswa mencatat informasi yang mereka dapatkan dalam pembelajaran. Langkah yang dilakukan yaitu dengan guru meminta siswa mencatat hal yang penting dan memberikan waktu untuk mencatat. Pada lembar observasi siswa, hal yang belum berhasil atau masih tergolong kurang pada siklus II yaitu siswa belum mencatat semua informasi yang didapatkannya. Langkah yang dilakukan yaitu dengan guru meminta siswa mencatat hal yang penting dan memberikan waktu untuk mencatat, dan siswa mencatat semua informasi yang didapatnya.

\section{Siklus III}

Berdasarkan hasil pengamatan dua orang pengamat untuk aktivitas kegiatan guru pada siklus III selama proses pembelajaran diperoleh rata-rata skor sebesar 28,5, 
rata-rata skor ini termasuk ke dalam kategori "Baik". Pada aktivitas siswa dapat dilihat rata-rata skor pada proses pembelajaran yang diamati oleh dua orang pengamat pada siklus III diperoleh rata-rata skor yaitu sebesar 31,5. Skor tersebut sudah tergolong ke dalam kategori sangat baik.

\section{Refleksi Aktivitas Pembelajaran Siklus III}

Berdasarkan lembar observasi guru dan siswa pada siklus III tidak terdapat lagi aspek yang termasuk dalam kriteria kurang dan cukup. Aspek ada lembar observasi guru dan siswa pada kedua pengamat sudah tergolong baik dan sangat baik.

\section{b. Deskripsi minat belajar matematika siswa Siklus I}

Berdasarkan angket minat belajar siswa didapatkan total skor perolehan pada siklus I yaitu 194, rata -rata 77,6 \% yang tergolong ada kriteria tinggi, hal ini dikarenakan sebanyak 77,6 \% siswa menjawab "ya" pada angket tersebut.

\section{Refleksi Siklus I}

Adapun point siswa yang menjawab tidak ada pada pertanyaan yaitu: 1) saya suka mengajarkan teman sekelmpok, 2) saya menjawab soal dengan cepat. Langkahlangkah yang dilakukan untuk perbaikan aspekaspek tersebut yaitu: 1) Seharusnya guru memberi pemahaman pada siswa bahwa kerja kelompok dilaksanakan dengan bekerja sama dan siswa yang mengerti harus mengajarkan teman sekelompoknya yang belum mengerti, 2) Seharusnya guru memberi motivasi pada siswa bahwa bila menjawab soal dengan cepat dan benar maka mereka akan mendapatkan hadiah dan soal dikerjakan bersama-sama dengan kelompok masing-masing atau tidak dikerjakan secara individu.

\section{Siklus II}

Berdasarkan angket minat belajar siswa didapatkan total skor perolehan pada siklus II yaitu 215 dengan rata-rat skor $86 \%$ yang tergolong dalam kriteria sangat tinggi. Skor perolehan sudah meningkat dibandingkan pada siklus I yaitu mengalami peningkatan sebesar 8,4\% yaitu dari 77,6 \% pada siklus I dan meningkat sebesar 86 $\%$ pada siklus II.

\section{Refleksi Siklus II}

Berdasarkan angket minat belajar matematika siswa pada siklus II masih ada siswa yang berpendapat belum sesuai dengan harapan yaitu: 1) saya senang belajar sambil bermain, 2) saya menjawab soal dengan cepat. Langkah-langkah yang dilakukan untuk perbaikan aspek-aspek tersebut yaitu: 1) Seharusnya guru menegur siswa yang masih suka bermain saat pelajaran berlangsung. Guru meminta siswa lebih serius lagi agar hasil belajar mereka meningkat. 2) Seharusnya guru meminta siswa lebih cepat mengerjakan soal namun jawabannya benar dengan bekerja sama, bertukar pikiran dengan siswa yang kemampuan nya lebih tinggi.

\section{Siklus III}

Berdasarkan angket minat belajar siswa didapatkan total skor perolehan pada siklus III diperoleh skor sebesar 223, dengan rata-rata skor 89,2\% yang tergolong dalam kriteria sangat tinggi. Hal ini menunjukan bahwa sudah ada peningkatan dibandingkan pada siklus I dan II yaitu mengalami peningkatan sebesar 3,2\% yaitu dari $86 \%$ pada siklus II dan meningkat sebesar $89,2 \%$ pada siklus III. Rata-rata 
siswa sudah memiliki minat belajar matematika siswa yang sangat tinggi. Hampir semua siswa menjawab "ya" pada pertanyaan angket.

\section{Refleksi Siklus III}

Berdasarkan angket minat belajar matematika siswa pada siklus III hampir ratarata siswa sudah menjawab angket dengan sesuai harapan dan minat belajar matematika siswa sudah tergolong sangat tinggi.

\section{c. Deskripsi hasil belajar kognitif siswa}

Hasil belajar kognitif siswa pada siklus I, II, dan III dapat dilihat pada Tabel 3.1 berikut.

Tabel 3.1 Rekapitulasi Analisis Hasil

Belajar Siswa Siklus I, II, dan III

\begin{tabular}{|c|c|c|c|c|c|}
\hline Siklus & $\begin{array}{c}\text { Jumlah } \\
\text { Siswa }\end{array}$ & $\begin{array}{c}\text { Rata- } \\
\text { Rata } \\
\text { (SD) }\end{array}$ & $\begin{array}{c}\text { Siswa } \\
\text { yang } \\
\text { tuntas }\end{array}$ & $\begin{array}{c}\text { Siswa } \\
\text { yang } \\
\text { tidak } \\
\text { tuntas }\end{array}$ & $\begin{array}{c}\text { Ketuntasan } \\
\text { Belajar } \\
\text { Klasikal }\end{array}$ \\
\hline I & 25 & $\begin{array}{c}66,4 \\
(32,5)\end{array}$ & $\begin{array}{c}11 \\
(44 \%)\end{array}$ & $\begin{array}{c}14 \\
(56 \%)\end{array}$ & $44 \%$ \\
\hline II & 25 & $\begin{array}{c}69,4 \\
(24,2)\end{array}$ & $\begin{array}{c}16 \\
(64 \%)\end{array}$ & $\begin{array}{c}9 \\
(36 \%)\end{array}$ & $64 \%$ \\
\hline III & 25 & $\begin{array}{c}80,6 \\
(16,4)\end{array}$ & $\begin{array}{c}22 \\
(88 \%)\end{array}$ & $\begin{array}{c}3 \\
(12 \%)\end{array}$ & $88 \%$ \\
\hline
\end{tabular}

Berdasarkan Tabel 3.1 diketahui bahwa pembelajaran pada siklus I belum mencapai ketuntasan belajar klasikal karena kriteria keberhasilan dan ketuntasan belajar di SDN 69 Kota Bengkulu secara klasikal dikatakan berhasil jika 85\% siswa memperoleh nilai $\geq 70$. Pada siklus II menunjukkan bahwa terjadi peningkatan sebesar $20 \%$, yaitu dari $44 \%$ menjadi $64 \%$, maka pembelajaran pada siklus II belum mencapai ketuntasan belajar klasikal karena kriteria keberhasilan dan ketuntasan belajar di SDN 69 Kota Bengkulu secara klasikal dikatakan berhasil jika $85 \%$ siswa memperoleh nilai $\geq 70$. Pada Siklus II menunjukkan bahwa terjadi peningkatan $24 \%$ yakni dari $64 \%$ pada siklus II menjadi $88 \%$ pada siklus III, diketahui bahwa pembelajaran pada siklus III sudah mencapai ketuntasan belajar klasikal karena kriteria keberhasilan dan ketuntasan belajar di SDN 69 Kota Bengkulu secara klasikal dikatakan berhasil jika $85 \%$ siswa memperoleh nilai $\geq 70$.

\section{Refleksi Siklus I}

Berdasarkan hasil analisis terhadap hasil belajar kognitif matematika siswa pada siklus I, dari 25 siswa masih terdapat 14 siswa (56\%) yang belum tuntas (dengan nilai < 70). Langkahlangkah yang dilakukan untuk perbaikan tersebut yaitu: 1) Guru memberikan remedial pada siswa yang belum tuntas, 2) Guru memberikan penjelasan ulang mengenai materi yang belum mereka pahami, 3) Guru mengganti media peembelajaran yang kecil dengan menggunakan LCD pada siklus II agar lebih menarik dan semua siswa jelas melihat media pembelajaran tersebut, 4) Guru memberikan motivasi terhadap siswa dengan menjanjikan memberikan hadiah bila hasil belajar nya meningkat. 


\section{Refleksi Siklus II}

Berdasarkan lembar jawaban soal tes akhir siklus siswa pada siklus II dari 25 siswa masih ada 9 siswa yang belum tuntas. Langkah-langkah yang dilakukan untuk perbaikan nilai tersebut yaitu: 1) Guru memberikan remedial pada siswa yang belum tuntas sebanyak 9 siswa dengan materi konversi satuan waktu (lama suatu kegiatan), 2) Guru memberikan penjelasan ulang mengenai materi pada siklus II yaitu konversi satuan waktu (lama suatu kegiatan) yang belum mereka pahami, 3) Guru menyiapkan media pembelajaran berupa PPT menggunakan LCD pada siklus III agar lebih menarik dan semua siswa dapat melihat media pembelajaran tersebut lebih jelas karena tampilan lebih besar dari pada media pada siklus I, 4) Guru memberikan motivasi terhadap siswa dengan memberikan hadiah bila hasil belajar nya meningkat.

\section{Refleksi Siklus III}

Berdasarkan hasil lembar tes akhir siklus siswa pada siklus III, dari 25 siswa hanya 3 siswa yang belum tuntas. Maka sudah mencapai ketuntasan belajar klasikal siswa dan nilai rata-rata kelas juga sudah tinggi.

\section{Pembahasan}

Pada penelitian ini pembelajaran dilakukan dengan penerapan strategi pembelajaran quick on the draw untuk meningkatkan minat dan hasil belajar matematika siswa kelas II D SDN 69 Kota Bengkulu. Pada pembelajaran ini siswa menggunakan kartu soal, siswa ditempatkan dalam tim belajar yang beranggotakan 5 orang yang merupakan campuran menurut kemampuan akademik dan jenis kelamin. Hasil akhir dari penelitian pada pembelajaran yang telah dilaksanakan dalam 3 siklus ini ternyata dapat meningkatkan aktivitas pembelajaran, minat belajar, dan hasil belajar kognitif siswa.

Dari hasil analisis data observasi terhadap aktivitas guru pada proses pembelajaran siklus I sampai siklus III yang dilakukan dalam penelitian ini diketahui bahwa proses pembelajaran dapat menjadi lebih baik, artinya terjadi peningkatan rata-rata skor pengamatan pada siklus II dan III. Pada siklus I lembar observasi guru sudah tergolong cukup, dengan jumlah skor pengamatan yang didapat yaitu 22,5, meningkat pada siklus II yaitu sebesar 24,5 dan tergolong kategori baik, meningkat kembali pada siklus III sebesar 28,5 yang tergolong pada kategori baikUntuk meningkatkan aktivitas guru salah satu hal yang dilakukan guru yaitu dengan menggunakan media ajar berupa menampilkan slide PPT. Penggunaan slide PPT ini membantu guru menyampaikan materi pada siswa, media ini tidak pernah digunnakan di kelas ini sebelumnya. Sehingga, ketika guru menggunakan media menggunakan slide PPT, siswa antusias dalam memperhatikan penjelasan guru. Selain itu guru menggunakan kartu soal. Kartu soal yang digunakan terdiri dari 5 warna. Setiap kelompok memiliki warna yang berbeda. Fungsi warna yang berbeda yaitu agar siswa mengenali kartu soal kelompok masing - masing. Sehingga pada saat mereka berlomba mengambil kartu soal di meja guru tidak terjadi kesalahan dalam mengambil kartu soal. Hal ini sesuaidengan pendapat Slameto (2010:36), bahwa dalam proses mengajar belajar, guru perlu menimbulkan aktivitas siswa dalam berpikir dan berbuat. Dari hasil analisis data observasi terhadap aktivitas siswa pada proses pembelajaran siklus I sampai siklus III yang dilakukan dalam penelitian ini diketahui bahwa proses pembelajaran dapat menjadi lebih baik, artinya terjadi peningkatan rata-rata skor pengamatan pada siklus II dan III. Pada siklus I lembar observasi siswa sudah 
tergolong baik, dengan jumlah skor pengamatan yang didapat yaitu 25,5, meningkat pada siklus II yaitu sebesar 27 dan tergolong kategori baik, meningkat kembali pada siklus 3 sebesar 31,5 yang tergolong pada kategori sangat baik.

Aktivitas siswa meningkat dengan cara menggunakan kartu soal, siswa mengambil kartu soal dengan cepat agar kelompok mereka menang dalam perlombaan tersebut. Setelah mengambil 1 kartu soal mereka membawa kartu tersebut ke kelompok mereka agar dikerjakan bersama dalam kelompok. Setelah itu siswa bersama kelompoknya berdiskusi menjawab pertanyaan pada kartu soal. Siswa berdiskusi bersama kelompok masing- masing untuk menjawab pertanyaan dan bertukar pikiran dengan teman sekelompoknya untuk menjawab soal pada kartu soal. Mereka mengerjakan soal dengan cepat dan benar agar kelompoknya menjadi pemenang dalam perlombaan menggunakan kartu soal.

Hal ini sesuai denagn pendapat Hamalik dalam Pathoni dan Aminoto (2014:18-19) menyatakan bahwa aktivitas pembelajaran akan sangat berpengaruh selama proses pembelajaran berlangsung. Pengajaran yang efektif adalah pengajaran yang menyediakan kesempatan belajar sendiri atau melakukan aktivitas sendiri." Banyak sekali jenis-jenis aktivitas yang dapat dilakukan oleh siswa, tidak hanya mendengar dan mencatat. Indikator yang menyatakan aktivitas belajar yang dilakukan siswa antara lain sebagai berikut: membaca, melihat gambar - gambar, mengamati, mengamati orang lain bekerja, atau bermain, mengemukakan suatu fakta atau prinsip, menghubungkan suatu kejadian, mengajukan pertanyaan, memberi saran, mengemukakan pendapat, diskusi, mendengarkan penyajian bahan, mendegarkan percakapan atau diskusi kelompok, menulishasil diskusi, membuat rangkuman materi, mengerjakan tes, mengisi angket, menyelenggarakan permainan, mengingat, memecahkan masalah. Semua kegiatan-kegiatan tersebut dapat diaplikasikan dalam proses pembelajaran dengan memperhatikan kondisi saat proses pembelajaran berlangsung, untuk tercapainya tujuan pembelajaran yang direncanakan.

Berdasarkan analisis hasil angket minat belajar matematika siswa, pada siklus I minat belajar pada angket minat belajar matematika siswa sudah tergolong tinggi, hal ini dikarenakan sebanyak 77,6 \% siswa menjawab "ya "pada angket tersebut, kemudian meningkat pada siklus ke II yaitu $86 \%$ yang sudah tergolong sangat tinggi, kemudian meningkat kembali pada siklus ke III yaitu sebesar $89,2 \%$ yang tergolong sangat tinggi. Angket minat belajar matematika di isi oleh siswa dengan dipandu oleh guru. Peningkatan minat belajar matematika ini terjadi dikarenakan siswa memperhatikan penjelasan guru menggunakan media ajar yang menarik siswa untuk memperhatikan pelajaran dan juga penggunaan kartu soal membuat siswa merasa senang karena mereka bermain dan berlomba untuk menjadi pemenang. Hal ini sesuai dengan pendapat Slameto (2010:57), minat adalah kecenderungan yang tetap untuk memperhatikan dang mengenang beberapa kegiatan. Kegiatan yang diminati seseorang, diperhatikan terus menerus yang disertai dengan rasa senang.

Berdasarkan analisis hasil belajar kognitif matematika siswa, pada siklus I hasil belajar siswa dinyatakan tidak tuntas. Berdasarkan hasil wawancara guru terhadap siswa ketidaktuntasan pada siklus I disebabkan oleh adanya materi yang dirasakan sulit bagi siswa sehingga kurangnya minat siswa untuk menyimak penjelasan dari guru, dan siswa belum terbiasa menggunakan kartu soal. Hal ini membuat sebagian besar siswa tidak dapat menjawabnya dengan benar pada saat diberikan pertanyaan terkait materi tersebut pada soal tes akhir siklus. Namun pada siklus II hasil belajar siswa sudah meningkat dari pada 
siklus I, dan pada siklus III lebih meningkat lagi dari siklus sebelumnya dan secara klasikal dinyatakan tuntas $88 \%$. Meningkatnya ketuntasan belajar siswa disebabkan oleh semakin baiknya proses pembelajaran di siklus II dan III.

Hal ini sesuai dengan pendapat Firmansyah (2015:36) yang mengatakan bahwa minat seorang siswa juga akan mempengaruhi hasil belajarnya. Minat dapat diartikan sebagai keinginan yang besar terhadap sesuatu yang dimiliki oleh seseorang. Apabila seorang siswa mempunyai minat yang besarter hadap mata pelajaran matematika, maka ia ingin mengetahui secara mendalam materinya sampai ia memahaminya, sehingga ia akan mencapai hasil belajarnya yang lebih baik. Hal ini disebabkan karena siswa memahami konsep belajar matematika. Tetapi mungkin saja seorang siswa yang mempunyai minat yang besar terhadap matematika, hasil belajarnya kurang baik.

Dari pembahasan diatas, dapat disimpulkan bahwa penerapan strategi pembelajaran quick on the draw dapat meningkatkan aktivitas guru, aktivitas siswa, minat belajar siswa dan hasil belajar kognitif matematika ini. Hal ini terjadi karena pada strategi ini menggunakan kartu soal yang digunakan pada saat pembelajaran berlangsung sehingga aktivitas guru dan siswa meningkat karena adanya diskusi kelompok dan perlombaan pada saat pembelajaran dan secara tidak langsung akan membangkitkan minat belajar matematika siswa yang berdampak kepada peningkatan hasil belajar matematika siswa. Hal ini sesuai dengan pendapat Asih (2016:2) yang mengatakan bahwa quick on the draw adalah sebuah strategi dimana aktivitas belajar siswa dengan suasana permainan yang membutuhkan kerja kelompok dan kecepatan dalam menyelesaikan satu set kartu soal yang berisi soal-soal yang terkait dengan pembelajaran.

\section{Kesimpulan}

Dari hasil penelitian tindakan kelas ini dapat diambil kesimpulan, sebagai berikut:

1. Peningkatan dari tiap siklus seperti yang didapatkan dari analisa data observasi guru. Untuk aktivitas guru di siklus I diperoleh rata-rata skor 22,5, dengan kriteria cukup dan mengalami peningkatan di siklus II dengan perolehan rata- rata skor 24,5 dengan kriteria baik, dan meningkat kembali pada siklus III yaitu dengan rata-rata skor 28,5 dengan kriteria baik.

2. Untuk peningkatan aktivitas siswa pada siklus I diperoleh rata-rata skor 25,5, maka dengan kriteria baik dan terjadi peningkatan pada siklus II dengan perolehan skor menjadi 27 dengan kriteria baik. Kemudian meningkat kembali di siklus III yaitu dengan perolehan skor 31,5 dengan kriteria sangat baik.

3. Peningkatan minat belajar siswa yang diukur melalui angket minat siswa meningkat di setiap siklusnya. Peningkatan persentase pada siklus I sebesar 77,6 \% dengan kriteria "tinggi". Pada siklus II meninggat menjadi $86 \%$ dengan kriteria "sangat tinggi", dan kemudian mengalami peningkatan kembali pada siklus III sebesar 89,2 \% dengan kriteria "sangat tinggi".

4. Proses pembelajaran dengan Penerapan Strategi Pembelajaran Quick On The Draw dapat meningkatkan Hasil Belajar Matematika Siswa Kelas II D SDN 69 Kota Bengkulu. Hal ini dapat dilihat dari rata-rata nilai tes pada siklus I yaitu $66,4 \quad(\mathrm{SD}=32,5)$, kemudian meningkat pada siklus II yaitu rata-rata nilai $69,4(\mathrm{SD}=24,2)$ dan pada siklus III rata- rata nilai meningkat kembali menjadi 80,6 (SD = 16,4). Pada ketuntasan belajar klasikal juga mengalami peningkatan pada setiap siklus yaitu pada siklus I 
ketuntasan belajar klasikal sebesar $44 \%$, kemudian meningkat pada siklus II menjadi $64 \%$ dan pada siklus III sebesar $88 \%$.

\section{Referensi}

Ariawan, R. (2016). Pengaruh Pendekatan Pembelajaran Visual Thinking Disertai Aktivitas Quick On The Draw Terhadap Kemampuan Komunikasi Matematis Siswa , Suska Journal of Mathematics Education. 20-30.

Asih, S., \& Johan, A. (2016). Efektivitas Strategi Quick on The Draw pada Materi Tabung dan Kerucut di Kelas IX SMP Negeri 31 Surabaya

Firmansyah, Dani. (2015). Pengaruh Stategi Pembelajaran dan Minat Belajar Terhadap Hasil Belajar Matematika. Jurnal PendidikanUnsika, 34-44.

Huriyanti, L., \& Rosiyanti, H. (2017). Perbedaan Motivasi Belajar Matematika Siswa Setelah Menggunakan Strategi Pembelajaran Quick On The Draw. Jurnal Pendidikan Matematika, 65-75.Pathoni, H., \& Aminoto, T. (2014).

Penerapan Media E-Learning Berbasis Schoology Untuk Meningkatkan Aktivitas dan Hasil Belajar Materi Usaha dan Energi Di Kelas XI SMA N 10 Kota Jambi. Jurnal Sainmatika. 13-29.

Rusman. (2017). Belajar dan Pembelajaran Berorientasi Standar Proses Pendidikan. Jakarta: Kencana.

Slameto. (2010). Belajar dan Faktor yang Mempengaruhinya. Jakarta: PT. Rineka Cipta.

Suprihatiningrum, J. (2016). Strategi Pembelajaran. Yogyakarta: Ar- Ruzz Media.

Suryadinata, N. (2015). Pengembangan Perangkat Pembelajaran Strategi Quick On The Draw dengan Masalah Open Ended untuk Meningkatkan Kemampuan Berpikir Kreatif Materi Prisma dan Limas Jurnal Pendidikan Matematika FKIP Univ. Muhammadiyah Metro, 9-21.

Widiana, H. S. (2009). Landasan Konseptual Teoritik Psikologik dari Berbagai Teori Intelensi. Humanitas, 56-73.

Winarni, E. W. (2018). Teori dan Praktik Penelitian Kuantitatif Kualitatif Penelitian Tindakan Kelas (PTK) Research and Development (R\&D). Jakarta: Bumi Aksara. 